\title{
Chapter 13 \\ Diaspora Policies, Consular Services and Social Protection for Moroccan Citizens Abroad
}

\author{
Rilke Mahieu
}

\subsection{Diaspora Policy Infrastructure and Key Policies}

\subsubsection{The Moroccan Diaspora and its Relation with the Homeland}

Moroccans are currently one of the largest and most dispersed migrant populations in Europe, with large diaspora communities in France $(1,146,000)$, Belgium $(298,000)$, the Netherlands $(363,000)$, Italy $(487,000)$ and Spain $(766,000)$ and smaller ones in many other European countries, including Germany (127,000) (De Haas 2014). ${ }^{1}$

Europe's need of cheap labour after the Second World War has been an important driver for Morocco's post-war emigration (Charef 2014). Morocco's signature of a series of labour treaties with European states during the 1950s and 1960s can be put forward as the decisive factor of the twentieth century Moroccan emigration. While the initial labour migration wave was primarily low-skilled and male-dominated, this unidimensional picture should be nuanced in at least four ways. First, the presence of Moroccans in Europe is older than post-war migration, including Moroccan soldiers' participation in the World Wars. Second, Moroccan emigration has always been motivated by other than strictly economic factors, such as political repression under Morocco's authoritarian regime following independence. Third, after the abandonment of the labour recruitment treaties in 1973, Moroccan emigration continued, albeit in different shapes. Other types of Moroccan migration emerged such as (female) family reunification, student migration, high-skilled migration,

\footnotetext{
${ }^{1}$ Figures based on consular registration data.
}

R. Mahieu $(\triangle)$

University of Antwerp, Antwerp, Belgium

e-mail: rilke.mahieu@uantwerpen.be 
marriage migration, etc., thus adding to the diversity in the Moroccan expatriate population. Fourth, the Moroccan population abroad has expanded geographically to an increasing number of destinations. Initially, the Moroccan labour migration went to France, Belgium, the Netherlands and Germany (the four countries that had signed a labour treaty with Morocco). Among these, France was the primary destination, with population movements being anchored in the status of Morocco as a French protectorate until the Moroccan independence in 1956. From the 1970s and 1980s onward, while migration to the original destination countries continued, Spain and Italy emerged as new major destinations. Since then, Moroccan migration flows have also been oriented towards other European countries (e.g. the UK and Scandinavian countries), the United States and Canada (Fondation Hassan II \& IOM 2014). Since the 1990s, the Gulf has become an important destination (Ibid). In addition, large waves of Moroccan-Jewish migration have taken place from 1948 onward, primarily towards Israel, but also to France and North America (De Haas 2014).

The Moroccan population abroad, currently estimated by the Moroccan government at five million Marocains Résident à l'étranger (about $15 \%$ of the total Moroccan population), contributes in various ways to Morocco's economy and society. Most notably, there is an annual remittance flow of around $\$ 7$ billion (through official channels only). Remittances are the second source of hard currency after tourism receipts, which are also, to a large extent, provided by expatriate Moroccans during summer holidays (MPC 2013), as more than two million Moroccans return every year during holidays. Because of this significant financial input, the Moroccan population abroad is often depicted as the "cash cow" of Morocco. Many also own houses in Morocco, and at the community level, numerous small-scale non-governmental initiatives improve general welfare and contribute to local development in Morocco.

Since the beginning of Moroccan mass emigration in the early 1960s, there have been attempts by the Moroccan state to control the Moroccan population abroad and to manage and consolidate their economic contribution (Iskander 2010). However, Moroccan diaspora policies have changed significantly over time and are often described as an evolution from a repressive "long arm of Rabat" to a cooperative "outreached hand" (Bouras 2012). Notwithstanding this shift, distrust towards the Moroccan state persists among expatriate Moroccans. While it is difficult to make generalised claims, both historical (Iskander 2010) and contemporary experiences of non-resident Moroccans with origin-state institutions (represented, for instance, by police and consular staff (Kahmann 2014)), contribute to a general sense of distrust towards the Moroccan state. Diaspora policy institutions in particular are regularly being evaluated as inefficient, non-transparent and undemocratic (Belguendouz 2008; Østergaard-Nielsen 2012). More generally, major deficiencies in the Moroccan political system further spur a sceptical stance regarding Moroccan state's discourses and actions. 


\subsubsection{Diaspora Infrastructure}

Morocco's consular network spans all major destination countries. In each of the top five destination countries, there are several consulates whose number depends on the size and geographical dispersion of the Moroccan populations, as well as the size of the territory. There are 16 Moroccan consulates in France, 11 in Spain, 7 in Italy, 3 in Belgium and 4 in the Netherlands. Beside the consular infrastructure, mobile consulates offering similar services are organised, although on an irregular basis. In addition, Morocco has appointed 75 honorary consuls, mainly in countries and regions lacking consular representation.

While the Moroccan consular network is vast, the lack of quality of its services has been a source of frustration among Moroccans living abroad (Iskander 2010; Belguendouz 2006). Among others, Moroccans abroad complain about the very long waiting lines and unequal treatment due to favouritism. In response to this situation, the improvement of consular services has become a governmental priority since 2015, under the impulse of King Mohammed VI. ${ }^{23}$ Among others, a large number of consular employees were fired and replaced, and a hotline for complaints about the consular services was installed.

Beside the consular network operating under the Ministry of Foreign Affairs, various other Moroccan national institutions and foundations have an important stake in emigrant affairs. First, there is the Ministry Delegate to the Ministry of Foreign Affairs and International Cooperation, in charge of Moroccans Residing Abroad and Immigration Affairs (MDCMREAM). This Ministry is charged with the task of preparing and implementing the governmental policy regarding both Moroccans residing abroad and immigrants in Morocco, in cooperation with other ministries and institutions inside and outside Morocco in the realm of migration affairs. The Ministry for Moroccans living abroad was first created in 1990 and has taken different forms since then (sub-ministry, independent ministry). In its current form, it has operated since 2017, during the Othmani government.

Second, there is the Hassan II Foundation for Moroccans Residing Abroad. Created in 1990 and presided by the King's sister Lalla Meryem, ${ }^{4}$ this Foundation

\footnotetext{
${ }^{2}$ See the Royal Discourse of the 16th Coronation Celebration on July 15, 2015.

${ }^{3}$ In the latest governmental declaration (2016-2021), the following goal has been set "Completion of the consular reform project and the process of modernizing and improving the quality of consular and social services, for the benefit of members of the Moroccan community residing abroad, as part of a dedicated action program".

${ }^{4}$ It should be noted that while the Hassan II Foundation for Moroccans Residing Abroad and the Mohammed V Solidarity Foundation are, strictly speaking, non-political institutions, they are however very tightly connected to the monarchy, which is at the heart of political power in Morocco. The Hassan II Foundation has been designed as a quasi-governmental social aid agency, the major source of income constituting a direct contribution by the Moroccan financial institutions governing migrant remittances, based on a fixed interest rate on emigrant savings (Belguendouz 2006). The Mohammed V Solidarity Foundation's budget mainly stems from a committee of around 100 regular donors, including all major financial institutions and a range of other
} 
aims to support the ties between Moroccans living abroad and their home country and to help non-resident Moroccans to overcome difficulties resulting from their emigration. This institution organises language and cultural education and activities for children, offers judicial, economic and social assistance and promotes cooperation. In addition, it contains an observatory on Moroccan migration. ${ }^{5}$

Third, a national consultative body was created in 2007: the Council of the Moroccan Community Living Abroad (CCME). The CCME's responsibilities include the monitoring and evaluation of the country's public policies with regard to its nationals abroad. It is responsible for issuing notices to ensure the defence of the interests of overseas Moroccans and strengthening their contribution to the economic, social and human development of the country. Furthermore, it also aims to reinforce diplomatic relations and cooperation between Morocco and the countries of residence.

Fourth, since 2000, the Mohammed V Solidarity Foundation, a humanitarian organisation presided by King Mohammed VI, ${ }^{6}$ is in charge of the annual Marhaba mission, described as "a humanitarian mission consisting of the management of the transfer of 2.5 million Moroccans between their host countries in Europe and their home country, Morocco, during the summer season".

It should be noted that all diaspora institutions are situated at the national level, which reflects Morocco's centralised political system. ${ }^{7}$ While the presence of various diaspora institutions in Morocco indicates the importance adhered to emigration by the central authorities, it has also spurred the criticism that there are too many institutions with overlapping competencies in the field of Moroccan diaspora policies (Belguendouz 2006).

Regarding the target population of Moroccan diaspora policies, the most commonly used term for Moroccan nationals abroad is "MRE" (Marocains Résidant à l'Etranger or "Moroccans Living Abroad"), while "MDM" (Marocains du Monde or "Global Moroccans") is also increasingly used. These terms are used in the broadest sense possible. They include Moroccan emigrants and their foreign-born descendants (second, third and further generations). This inclusive understanding draws on the Moroccan Nationality Code according to which any child born of a Moroccan father or mother is a Moroccan citizen, irrespectively of the place of birth or residence (ius sanguinis principle). As the Moroccan nationality is granted automatically and cannot be renounced, all persons with Moroccan origins are automatically considered as "MRE". However, due to the ordinary naturalisation process and the acquisition of the host country's nationality at birth (ius soli principle), a large share of Moroccans abroad has dual nationality. For instance, in the

companies in Morocco. However, the nature of the budget of both foundations should not conceal that they are policy instruments employed by the monarchy.

${ }^{5}$ For an in-depth discussion of the relationship between the Ministry and the Hassan II Foundation, see Mahieu (2019).

${ }^{6}$ See footnote 4 .

${ }^{7}$ However, in 2008 a process of "advanced regionalisation" has started, with the aim of making the regions more autonomous. 
main destination country- France, approximately two out of three Moroccans have French nationality (Wels et al. 2015).

\subsubsection{Key Engagement Policies}

The Monarchy sets the course for Moroccan diaspora policies. King Mohammed VI (r.1999-present) and his predecessor and father Hassan II (r.1961-1999) have drawn the institutional outlines of these policies and define(d) to a large extent the policy agenda (Brand 2006). In addition, the new Moroccan Constitution (2011) provides some of the guiding principles for Moroccan diaspora policies. ${ }^{8}$ However, an integrated, transversal Moroccan diaspora strategy is non-existent.

As stipulated in Article 16 of the Constitution, the Moroccan state aims for the "strengthening of MREs' contribution to the development of their home country, Morocco, and the tightening of cordial and cooperative ties with the governments and societies of the destination countries". This illustrates well the Moroccan diaspora policies' focus on the contribution of Moroccans living abroad to the socioeconomic development of Morocco. Traditionally, Moroccans living abroad have sent large flows of remittances, which are facilitated by several Moroccan banks having agencies in the major destination countries (e.g. Banque Populaire and Atijariwafa Bank). While remittances are still considered important, current diaspora policies focus more on the mobilisation of Moroccan human resources and investment capital. Through supporting transnational entrepreneurship (e.g. by offering individual guidance to start-ups), stimulating investment in real estate and other sectors (through reduced taxation rates and targeted investment programs), setting up platforms to mobilise and create business networks (such as Maghribcom) and disseminating information, the Moroccan state takes an active role in this field. ${ }^{9}$ Characteristic for policies linking "migration" and "development" is that commonly supranational, regional and other international institutions are involved. Examples of international actors involved in this branch of Moroccan diaspora policies are the International Organisation for Migration, the European Union, the United Nations and development agencies of several receiving countries. ${ }^{10}$ Usually, external actors provide a large share of the funding for these policies. Depending on the partnership configuration, initiatives in this field are sometimes oriented towards specific segments of the Moroccan expatriate population. ${ }^{11}$

\footnotetext{
${ }^{8}$ Art. 16, 17, 18, 30 and 163.

${ }^{9}$ On Morocco's mobilisation strategy, El Asri (2012).

${ }^{10} \mathrm{~A}$ good example here is SHARAKA, a project co-financed by the EU Commission, France and the Netherlands (www.sharaka.ma). This project ran between 2014 and 2017 and was part of the broader EU-Morocco Mobility Partnership, established in 2013.

${ }^{11}$ For instance, the Maghrib Entrepreneurs Program offers support to Moroccan-French entrepreneurs in France and Morocco with their start-up business in Morocco. The program was run in 2014-2015 by the MDCMREAM in cooperation with l'Agence Française de Développement.
} 
Beside the socio-economic focus, the ideas of maintaining cultural ties and preservation of the national identity take a pivotal position in Moroccan diaspora policies and discourses (Mahieu et al. 2017; Mahieu 2019). To these aims, several learning programs are being implemented, including Arabic Language and Moroccan Cultural Education (ELACM) in major destination countries and an online Arabic language-learning platform (e-Madrassa), both coordinated by the Hassan II Foundation. In addition, homeland tours or immersion programs are offered to different age groups, with the aim of immersing children and youngsters in the Moroccan culture, history and society. Examples of these programs are the Seasonal Universities for students in higher education aged between 18-25 (organised by the MDCMREAM) and summer camps for children (organised by the Hassan II Foundation) (Mahieu 2015). Beside visiting programs, Moroccan diaspora institutions also aim at supporting the proliferation of the Moroccan cultural life in the host societies, for instance by supporting Moroccan theatre tours and by creating Moroccan cultural centres (both initiated by the MDCMREAM).

While legally, Moroccan nationals living abroad are entitled to vote and to be eligible in legislative elections at the national, regional and local level (2011 Constitution, Article 17 and Article 30), in practice, this right is not implemented by the Moroccan state. According to the Ministry of Interior Affairs, logistic and diplomatic obstacles for the creation of a constituency abroad in the destination countries impede the electoral participation of nationals living abroad. ${ }^{12}$

Concerning return migration, returnees currently receive little support from the Moroccan state (SHARAKA 2015). However, policy strategies on return migration are emerging (Cherti et al. 2013), and targeted support initiatives are being set up. ${ }^{13}$

\subsection{Diaspora Policies and Social Protection in Morocco}

Pivotal for the social protection of Moroccans nationals living abroad are the Bilateral Conventions on Social Security. In response to large-scale Moroccan labour emigration since the 1960s, Morocco has signed Bilateral Conventions with a number of destination countries for Moroccan emigrants. ${ }^{14}$ Among the top five destination countries, four have concluded bilateral agreements on social security

\footnotetext{
${ }^{12}$ However, during the period 1985-1989, Moroccan nationals abroad were able to directly elect five representatives in parliament (Iskander 2010).

${ }^{13}$ In 2017, a convention was signed between the Ministry for Moroccans Living Abroad, and the Regional Council of Beni Mellal-Khenifra on the establishment of a reception centre for MRE, which would be the first one in Morocco. The centre will aim at both temporary visitors as returnees, and would offer a broad range of administrative and cultural services and leisure.

${ }^{14}$ Morocco has signed Bilateral Social Security Conventions with 14 countries: Belgium, the Netherlands, Spain, Sweden, Germany, Libya, Denmark, Romania, Tunisia, Canada, Portugal, Québec, France, and Luxembourg. With several others, negotiations are continuing.
} 
with Morocco: France (2007), ${ }^{15}$ Spain (1979), Belgium (1968), and the Netherlands (1972). A similar Bilateral Convention with Italy has been drafted in 1994, but due to Italy's refusal to sign it, it has not been implemented.

All Conventions include key principles such as: the fact that the primary legislation is the one of the country of labour (i.e. the country of residence); equal treatment of nationals and expatriate workers; the exportability of benefits that are normally subject to the residence condition (such as pensions and child benefits); the coordination of the social security systems of both parties. As such, the Conventions guarantee that Moroccan nationals working abroad have the same social security rights and obligations as employed citizens of their residence countries. They also ensure that, under certain conditions, Moroccan nationals, receive Moroccan social security benefits while living abroad and, in case of return to Morocco, that social rights built up in the destination country are exportable to Morocco. Finally, such Conventions also guarantee that periods of activity in both countries are totalised for their entitlement to social security benefits and for the calculation of these benefits.

However, the Conventions only cover contributory benefits (i.e. benefits the person has contributed to directly, as part of an insurance system) and benefits based on non-contributory solidarity mechanisms (welfare redistribution drawing on the taxes paid by all tax payers) are not included (Wels et al. 2015). Also, the Conventions only cover Moroccan nationals (and their dependants) with a legal residence status, who are also workers (or have an equivalent status) in their residence countries. ${ }^{16}$

In addition to bilateral relations, the protection of social rights of Moroccans in Europe is also affected by European harmonization processes. For instance, the Euro-Mediterranean Agreement, ${ }^{17}$ signed in 2000 by Morocco and the EU Member States, also addresses the social protection of Moroccans in European countries. While primarily a trade agreement, Article 65 of the Euro-Med Agreement concerns social security. It establishes the principle of equal treatment of Moroccan nationals and the citizens of EU Member States in the domain of social security, ${ }^{18}$ the principle of exportability of social rights from one country to another when nationals move, and the aggregation of activity periods of Moroccan nationals in different EU Member States for the entitlement to and calculation of certain social security benefits. ${ }^{19}$ However, the Euro-Med Agreement's provisions are not directly implementable

\footnotetext{
${ }^{15}$ Original Convention signed on 9-7-1965, revised Convention signed in 2007.

${ }^{16}$ The various Bilateral Social Security Conventions differ in what refers to the categories of employees that they cover. Often, only employed workers are covered, but the French-Moroccan and Spanish-Moroccan Bilateral Conventions, also include self-employed workers (but only France and Spain do so, not the Moroccan state).

${ }^{17} \mathrm{http} / / /$ trade.ec.europa.eu/doclib/docs/2006/march/tradoc_127906.pdf

${ }^{18}$ However, this non-discrimination principle has been underpinned by EU Members States earlier by the ratification of the International Labour Organisation's Migration for Employment Convention $\mathrm{N}^{\circ} 97$ (1949) in the 1950s and 1960s.

${ }^{19}$ The accumulation of social rights across Member States is important, as there have been significant migration flows of Moroccan nationals from Southern to Northern European countries during
} 
(since regulatory instruments are needed). To take effect, the agreement still needs to be endorsed by the Morocco-EU Association Council (García de Cortázar Nebreda 2016). Notwithstanding, the European Court of Justice has ruled that the non-discrimination principle in social security is directly implementable anyway (Eisele 2014). ${ }^{20}$ Also, the principle of aggregation of the beneficiary's periods of activity in different Member States is effective yet (García de Cortázar Nebreda 2016).

While there are overlaps between the protection offered by the Euro-Med Agreement on the one hand, and the Bilateral Conventions on the other hand, the Conventions offer a far more comprehensive social protection. These differences explain why Morocco continues to prioritize a bilateral strategy, by initiating or continuing bilateral negotiations with other destination countries (like Norway), renegotiating existing conventions (for instance, with France in 2007) and concluding new administrative arrangements to specify the application of the existing conventions (for instance, with Belgium in 2014). ${ }^{21}$ While the social protection offered by the Conventions has become more extensive over the years in several cases (e.g. Belgium and France), an inverse tendency of more restrictive application may be noted in the case of the Netherlands. In 2016, the Dutch government announced to lower certain benefits of Moroccan nationals' dependants living in Morocco ${ }^{22}$ this decision being justified by the Dutch government by the lower cost of living in Morocco compared to the Netherlands. While the Moroccan government and diaspora institutions initially contested the decision as unfair, the dispute was settled in favour of the Dutch position.

Beside the provisions defined in bilateral and European agreements, the social protection of Moroccans living abroad receives only limited attention by Moroccan public institutions. There is no systematic dissemination of information on the social protection of nationals abroad, or on the application of the relevant bilateral and EU agreements in particular. Information is disseminated on an irregular basis or to limited audiences, such as through the publication of studies (e.g. by the CCME), the organisation of conferences (e.g. by the Hassan II Foundation) or by organising information sessions (by the National Social Security Fund, CNSS). ${ }^{23}$ Sometimes, information gaps are addressed by campaigns of international or foreign national development agencies, ${ }^{24}$ or by host country institutions. A recent study on Morocco's Bilateral Social Security Conventions with Belgium and France found that information provision by the host country institutions is seen by beneficiaries as effective,

the latest European economic crisis.

${ }^{20}$ Case C-18/90 Kziber (1991) ECJ I-199.

${ }^{21}$ In 2014, a new administrative arrangement was signed, consolidating returning Moroccan pensioners' rights to health care in Morocco.

${ }^{22}$ In particular, dependant widows and children of emigrants would be affected by the measure and lose up to $40 \%$ of their benefits.

${ }^{23}$ For studies, see CCME (2016a) and CCME (2016b). The Hassan II Foundation organised the conference «Le troisième âge des Marocains résidant à l'étranger » in June 2005 in Rabat.

${ }^{24}$ For instance, with regard to return migration to Morocco, a guide has been developed by the SHARAKA consortium, also covering the issue of social security: http://www.sharaka.ma/assets/ Uploads/Guide-MRE-Version-Francaise2.pdf 
while information provision by Moroccan public institutions is considered inadequate as administrative staff is often ill-informed (Holzmann 2016).

With regard to the Moroccan consular network, enhancing access to the Moroccan social security protection is not considered a core task of consulates, nor do they assist Moroccan nationals abroad in accessing host country benefits. Consulates do not offer in-kind or cash assistance to nationals abroad and consular services are usually limited to arranging civil and administrative affairs. Helping Moroccans in dealing with social protection in Morocco or in the destination country is not a part of consulates' formal mission.

As most Moroccan nationals abroad live in stable welfare democracies, repatriation in order to ensure the safety of nationals abroad is usually not at stake. However, Article 56 of the decree regulating consular activities ${ }^{25}$ defines that, if the citizen abroad is in need and does not receive any support yet by the receiving state, cash or in-kind assistance may be provided, including repatriation. However, the Moroccan state may demand a reimbursement for a period up to 3 years after repatriation in case the repatriated citizen (or the head of household of his/her family) turns out to have means in Morocco. Beside the consulates, also the Hassan II Foundation offers repatriation services to particular categories of vulnerable Moroccans. Sick persons or those in need can file a request with the Foundation for repatriation support. Under exceptional circumstances (such as civil war), repatriation is considered on a more collective basis. This has been the case for Moroccan nationals living in Libya. In 2011, the Ministry of Foreign Affairs established a "crisis cell" with the aim of following up political events in Libya and taking necessary measures, including potential repatriation of Moroccan nationals. In addition, there have been several "repatriation operations" for liberating Moroccan migrants incarcerated in Libya in the context of the European battle against clandestine migration to Europe and enabling them to return to Morocco.

No general state policy exists regarding the repatriation of the remains. Repatriation costs are normally covered by special (private) insurances. However, if a Moroccan national abroad dies without an insurance and the family has no means, the Moroccan state covers the cost of repatriation. Both the Hassan II Foundation and the Ministry for Moroccans Living Abroad include in their services the coverage of the cost of repatriation of the body to Morocco, partially or totally. Candidatebeneficiaries (i.e. family members) have to file a demand with the Ministry (via the local consulate) or the Foundation Hassan II.

\subsubsection{Unemployment}

The Social Security Conventions with France and Spain and the Euro-Med Agreement do not take into consideration the coordination of unemployment benefits. As a general rule, unemployment benefits are considered as non-exportable. In

\footnotetext{
${ }^{25}$ Décret n ${ }^{\circ}$ 2-66-646 du 21 kaada 1389 (29 janvier 1970) portant application du dahir $\mathrm{n}^{\circ}$ 421-66 du 8 chaabane 1389 (20 octobre 1969) relatif aux attributions des agents diplomatiques et des consuls à l'étranger.
} 
the Euro-Med Agreement, it is mentioned though that Moroccan nationals, with regard to all social security matters - including unemployment - should receive a "treatment free from any discrimination based on nationality relative to nationals of the Member States in which they are employed" (Art. 65.1).

However, the Bilateral Social Security Conventions that Morocco signed with the Netherlands and Belgium introduce one coordination measure concerning unemployment: to determinate the right to unemployment benefits, the insurance periods of Moroccan nationals during their residency in Morocco and abroad will be aggregated (i.e. the periods the person has worked, or any equivalent period, such as the maternity leave).

Beside these legal provisions, the Moroccan state has also adopted a more proactive strategy regarding unemployment among Moroccan nationals abroad: a vocational training program benefitting young Moroccans abroad in a difficult social situation. The program was launched in 2011 by the Ministry Delegate to the Ministry of Foreign Affairs and International Cooperation, in charge of Moroccans Residing Abroad and Immigration Affairs. It particularly targets young nationals abroad in a number of Arab and African countries (Algeria, Tunisia, Libya and Senegal), and aims at stimulating their economic integration in the host societies. Candidates are selected via the embassies and consulates in those countries. The program aims at the acquisition of vocational skills during a 6-8 months training in Morocco, and is implemented in cooperation with the Professional Training and Labour Promotion Office (OFPPT) and the Ministry of Crafts, Social and Solidary Economy. However, it is a small-scale program with only $30-40$ beneficiaries each year.

\subsubsection{Health Care}

The access to general health care, maternity benefits and benefits related to occupational accidents or occupational diseases are provided by the Bilateral Conventions that Morocco signed with France, Spain, Belgium and the Netherlands. These Conventions ensure that Moroccan nationals are entitled to a health care insurance under the same conditions as the citizens of the country of residence. The Conventions also protect the dependants of the insured person. Also, upon return to Morocco, Moroccan pensioners are entitled to health care insurance (AMO) in Morocco. ${ }^{26}$

Moroccans nationals in Italy are not covered by a Bilateral Convention, although they are entitled to health care insurance in Italy under the same conditions as Italians through the non-discrimination clause in the Euro-Med Agreement and other treaties (see above). Contrary to their co-nationals in the other top five

\footnotetext{
${ }^{26}$ This is a recent measure, as AMO was introduced in Morocco in 2006.
} 
destination countries, dependants of Moroccans residing in Italy are protected only if they also reside in Italy, not in Morocco.

Beside the obligatory health care insurance (Assurance Maladie Obligatoire AMO, introduced in 2005), covering illness, maternity and accidents, Morocco has introduced the medical assistance program RAMED since 2008. It provides free or partially free medical services in public hospitals in Morocco to the most disadvantaged who are not covered by any health care insurance. Currently, the program is only accessible for Moroccans living in Morocco, but since 2013, the extension of the program to expatriate Moroccans nationals (who return to Morocco) and their dependants has been "under study" by the Health Care Ministry.

During their stay in Morocco over summer, expatriate Moroccans can also benefit from the basic health care provided by the annual Marhaba operation. The Mohammed V Foundation is in charge of assisting them in this period, such assistance encompassing administrative, legal and medical help. In transit regions (airports, ports, stations) and throughout Morocco, 20 temporary support centres are equipped with around 800 medical staff members and social assistants. The medical aid provided concerns mainly first aid in case of emergencies occurring during expatriate Moroccans' journey to Morocco (e.g. traffic incidents), including assistance to the victim's family members.

\subsubsection{Pensions}

As the demographic profile of the Moroccan expatriate population is shifting, the exportability of old-age pensions is a relevant issue. In main destination countries (France, Belgium, Germany, the Netherlands), where the Moroccan population is ageing rapidly (Fondation Hassan II 2006), the question of return is particularly at stake. The Bilateral Social Security Conventions cover this issue. Retired Moroccans who return to Morocco permanently continue to receive the pensions they were entitled to in the receiving country. In case the pensioner deceases, the dependants are usually entitled to a survivor's pension, no matter whether they live in Morocco or in the destination country. Only Spain maintains a residence requirement (CCME 2016a).

However, the principle of exportability only applies to regular pensions, not to any (non-contributory) top-ups that are offered in the receiving countries to pensioners with a pension below the minimum income. This is an important aspect, as approximately one out of three Moroccan pensioners living abroad benefit from such top-ups (Holzmann 2016).

Beside the legal provisions regarding pensions, there are also support programs for old Moroccans living abroad. One of the Moroccan diaspora institutions, the Hassan II Foundation, considers the elderly as an important target group of its "Cooperation and Partnership program". In this social program (in place since 1998), NGOs or other institutions or individuals working with retired Moroccans abroad can request the support of the Foundation Hassan II for their projects (partial 
financial support or in-kind support). In some of the implemented projects, the aim was to enhance the access of Moroccan pensioners to their social rights, but many projects focus more broadly on the elderly's well-being and their ties to Morocco.

\subsubsection{Family-Related Benefits}

The Bilateral Social Security Conventions that Morocco signed with four of the top five receiving countries guarantee Moroccans' access to family benefits even when the dependants (spouse and children) are residing in Morocco. ${ }^{27}$ In contrast, the EuroMed Agreement only guarantees family benefits when the children are residing with the worker in an EU Member State. As a result, Moroccan heads of households working in Italy are not entitled to family benefits when their children are living in Morocco.

In 2010, a scholarship program was launched to support the school careers of Moroccan youngsters abroad. The Ministry Delegate to the Ministry of Foreign Affairs and International Cooperation, in charge of Moroccans Residing Abroad and Immigration Affairs (MDCMREAM), together with the Ministry of Higher Education, Academic Research and Professional Training offers 1000 university scholarships annually to students in a "precarious situation". Their candidacy is made via the local consulate and the selection process is done by a Commission including members of both Ministries. The scholarship is limited to one student per family and the monthly allowance is around 1000 Moroccan Dirham (= around $€ 100$ ).

For Moroccan families living in Algeria and the Ivory Coast, there is another specific school support program. Deprived families can apply for financial support helping to cover their children's school fee. The aim is to boost school attendance by this group. The MDCMREAM provides support to 1000 Moroccan families in Algeria and 120 in the Ivory Coast. The fee depends on the number of children in the family (one child: 1000 Moroccan Dirham per year, 500 Dirham extra per child, up to a maximum of 5 children.)

\subsubsection{Economic Hardship}

The Moroccan state does not provide guaranteed minimum resources for Moroccans in Morocco. Therefore, unsurprisingly, there are no provisions to guarantee minimum resources for Moroccans living abroad. In the residence countries, guaranteed minimum resources are considered as non-contributory benefits and therefore nonexportable. To benefit from them, the Moroccans beneficiary needs to reside in the receiving country.

\footnotetext{
${ }^{27}$ Sometimes, there is a restriction with regard to the number of children abroad creating an entitlement to family benefits. For instance, the French-Moroccan Social Security Convention defines a limit of four children.
} 
However, in 2013, the government has launched the idea to offer in-cash assistance to needy nationals abroad. The former prime minister announced the creation of a National Solidarity Fund for Moroccan nationals living abroad who find themselves in a precarious situation. The aim would be to help the "most vulnerable or needy citizens abroad". The Solidarity Fund would contain ten million Moroccan Dirham (= $€ 1$ million.) and allocation of money would operate via consulates and embassies. However, this Fund does not seem to be operational (yet), and it is unclear who would benefit from it and under what conditions.

The lack of guaranteed minimum resources does not mean that Moroccan nationals who do not have an income are left to their fate. Due to the extensive social protection in Europe (where the largest share of the Moroccan population abroad is located), foreign nationals including Moroccan nationals are usually entitled to welfare benefits in the country of residence, although eligibility criteria vary across countries. However, Moroccan institutions (consular services, diaspora institutions) do not offer assistance to Moroccans living abroad in accessing these welfare benefits.

\subsection{Conclusions}

The focus of Moroccan diaspora policies is the mobilisation of Moroccan nationals' human and financial capital for socio-economic development in Morocco. Social protection of nationals abroad does not take a central position on the political agenda. When considering the state of the Moroccan society, with relatively high poverty and unemployment rates $^{28}$ and an emerging Moroccan social security system, this lack of prioritization of expatriate nationals' social protection is not surprising.

However, some important steps have been taken in this regard. The primary tools for expatriate nationals' social protection are a series of Bilateral Social Security Conventions that Morocco negotiated with top destination countries, including France, Spain, Belgium, and the Netherlands. These Conventions pursue coordination of the social security systems of Morocco and the destination countries and allow the exportability of (contributory) social benefits from origin to destination countries and vice versa. In the second place, harmonising EU policies towards its Mediterranean neighbours have also led to some coordination in the protection of social rights. This is especially important for Moroccans living in countries that have not signed a Social Security Convention with Morocco, such as Italy.

While the Bilateral Conventions perform quite well (Holzmann 2016), there is room for improvement. Among others, information dissemination on social rights

\footnotetext{
${ }^{28}$ General living standards in Morocco are moderate (Human Development Index: 0,647; position 123 out of 188 countries). Out of a population of 35 million, four million Moroccans live under the poverty line, while another 5.3 million live under the threat of falling back into poverty (World Bank 2017). In addition, unemployment rates have been rising steadily, fluctuating around $10 \%$ from 2014 on and hitting both rural populations and urban youth.
} 
could happen more systematically and more effectively by Moroccan public institutions. Due to the profile of the Moroccan population abroad (e.g. among retirees, a large share of low-educated or illiterate persons), it is likely that a share of the potential beneficiaries is currently not very well informed about their social security rights. Also, Bilateral Conventions do not consider social protection comprehensively as they focus on contributory benefits exclusively. Moreover, many territorial gaps remain as various important destination countries of Moroccan emigrants are not covered by a convention (e.g. the Gulf Countries, the USA, Italy). Moreover, the Bilateral Conventions are unable to guarantee the social security rights of Moroccan nationals with more complex migration trajectories (García de Cortázar Nebreda 2016).

Beside legal provisions that are coordinating the social security systems of home and host countries, there are a few programs offering support to particular categories of vulnerable groups such as elderly, disadvantaged youth or sick persons. However, social programs are usually not integrated in the state's consular services, but provided by other public institutions. In addition, these programs tend to be small-scale (benefitting only a small group of beneficiaries) and/or targeting specific receiving countries, rather than being generalised, comprehensive social protection policies for Moroccans abroad.

Acknowledgements This chapter is part of the project "Migration and Transnational Social Protection in (Post)Crisis Europe (MiTSoPro)" that has received funding from the European Research Council (ERC) under the European Union's Horizon 2020 research and innovation programme (Grant agreement No. 680014). In addition to this chapter, readers can find a series of indicators comparing national social protection and diaspora policies across 40 countries on the following website: http://labos.ulg.ac.be/socialprotection/.

\section{References}

Belguendouz, A. (2006). Marocains du Pays ET Marocains D'Ailleurs. Fracture Citoyenne? Salé: Imprimerie Beni Snassen.

Belguendouz, A. (2008). Conseil (non supérieur) hogra des mouhajirines. Les quatres vérités! Salé: Imprimerie Beni Snassen.

Bouras, N. (2012). Het Land van Herkomst. Perspectieven op Verbondenheid met Marokko 1960-2010. Hilversum: Uitgeverij Verloren.

Brand, L. A. (2006). Citizens abroad. Emigration and the state in the Middle East and North Africa. Cambridge: Cambridge University Press.

CCME - Conseil de la Communauté Marocaine à l'étranger. (2016a). La protection sociale des immigrés marocains: le cas de l'Espagne. Études et Recherches Groupe de Travail Administration, Droits des Usagers et Politiques Publiques. Rabat: CCME.

CCME - Conseil de la Communauté Marocaine à l'étranger. (2016b). La protection sociale des immigrés marocains: les retraites marocains en France. Quelles perspectives ? Études et Recherches Groupe de Travail Administration, Droits des Usagers et Politiques Publiques. Rabat: CCME.

Charef, M. (2014). Chapitre 10. Les Marocains et les Maroco-descendants de France. In Fondation Hassan II pour les Marocains Résidant à l'étranger \& Organisation Internationale pour les Migrations (Marocains de l'extérieur 2013) (pp. 311-338). Rabat: FHII \& IOM. 
Cherti, M., Balaram, B., \& Szilard, M. (2013). Retours des migrant's irréguliers au Maroc. Quelle politiques de réintégration? London: Institute for Public Policy Research.

de Haas, H. (2014). Chapitre 2. Un siècle de migrations marocaines: Transformations, transitions et perspectives d'avenir. In Fondation Hassan II pour les Marocains Résidant à l'étranger \& Organisation Internationale pour les Migrations (Marocains de l'extérieur 2013) (pp. 61-91). Rabat: FHII \& IOM.

Eisele, K. (2014). The external dimension of the EU's migration policy. Different legal positions of third-country nationals in the EU: A comparative perspective. Leiden/Boston: Brill Nijhof.

El Asri, F. (2012). Migrations Marocaines. Les compétences marocains de l'étranger: 25 ans de politiques de mobilisation. Rabat: CCME.

Fondation Hassan II pour les Marocains Résidant à l'Étranger, Observatoire de la Communauté des Marocains Résidant à l'Étranger. (2006). Marocains Résidant à l'Etranger: le Troisième âge. Rabat: FHII.

Fondation Hassan II pour les Marocains Résidant à l'Étranger, Observatoire de la Communauté des Marocains Résidant à l'Étranger \& International Organization for Migration. (2014). Marocains de l'Extérieur. Rabat: FHII.

García de Cortázar Nebreda, C. (2016). Coordination of social security schemes between the European Union and Euromed countries: Study. European Economic and Social Committee. https://www.eesc.europa.eu/en/our-work/publications-other-work/publications/coordination-social-security-schemes-between-european-union-and-euromed-countries. Accessed 7 Mar 2019.

Holzmann, R. (2016). Bilateral social security agreements and pensions portability: A study of four migrant corridors between EU and non-EU countries. International Social Security Review, 69(3-4), 109-130. https://doi.org/10.1111/issr.12110.

Iskander, N. (2010). Creative state. Forty years of migration and development policy in Morocco and Mexico. New York: Cornell University Press.

Kahmann, M. (2014). Ontmoetingen tussen de Marokkaanse Nederlanders en de Marokkaanse Overheid. Een antropologisch perspectief. PhD dissertation, University Leiden, Leiden.

Mahieu, R. (2015). Feeding the ties to 'home': Diaspora policies for the next generations. International Migration, 53(2), 397-408. https://doi.org/10.1111/imig.12183.

Mahieu, R. (2019). Competing origin-country perspectives on emigrant descendants: Moroccan diaspora institutions' policy views and practices regarding the "next generation abroad". International Migration Review, 53(1), 183-209. https://doi.org/10.1177/0197918318768556.

Mahieu, R., Timmerman, C., \& Fadil, N. (2017). The shifting Moroccan policy paradigm regarding the integration of MREs (Moroccans Living Abroad): Reconciling transnational ties and migrant integration. In C. Timmerman, N. Fadil, N. Clycq, \& K. Ettourki (Eds.), Moroccan migration in Belgium: More than 50 years of settlement. Leuven: Leuven University Press.

MPC - Migration Policy Centre. (2013). Migration profile: Morocco. Online report. https://library. euneighbours.eu/content/carim-migration-profile-morocco-2013. Accessed on 7 Mar 2019.

Østergaard-Nielsen, E. (2012). Political liberalizations and contestation of transnational relations between Morocco and Moroccan migrants in Spain. In P. Mandaville \& T. Lyon (Eds.), Politics from afar: Transnational diasporas and network (pp. 69-87). New York: Hurst/Columbia University Press.

SHARAKA. (2015). Rapport: La Reintegration des MRE au Maroc. Bilan des Membres du Groupe de Travail Sharaka. Online report http://www.sharaka.ma/dmsdocument/1. Accessed 9 May 2018.

Wels, J., Bensaid, N., \& Legros, F. (2015). La transportabilité des prestations de sécurité sociale. Retraite, de soins et de minimas sociaux (Hommes et Migrations, 1309 "Le troisième âge des immigrants") (pp. 107-115).

World Bank. (2017). US\$150 million to enhance social programs and support small enterprises in Morocco. Press Release. http://www.worldbank.org/en/news/press-release/2017/03/10/150million-us-dollars-to-enhance-social-programs-and-support-small-enterprises-in-morocco. Accessed on 9 May 2018. 
Open Access This chapter is licensed under the terms of the Creative Commons Attribution 4.0 International License (http://creativecommons.org/licenses/by/4.0/), which permits use, sharing, adaptation, distribution and reproduction in any medium or format, as long as you give appropriate credit to the original author(s) and the source, provide a link to the Creative Commons license and indicate if changes were made.

The images or other third party material in this chapter are included in the chapter's Creative Commons license, unless indicated otherwise in a credit line to the material. If material is not included in the chapter's Creative Commons license and your intended use is not permitted by statutory regulation or exceeds the permitted use, you will need to obtain permission directly from the copyright holder. 